\title{
ARTÍCULOS
}

\section{NEWS AND SOCIAL NETWORKS: AUDIENCE BEHAVIOR}

\section{Información de actualidad y redes sociales: comportamiento de las audiencias}

\author{
Pere Masip, Javier Guallar, Jaume Suau, Carlos Ruiz-Caballero and Miquel Peralta
}

Nota: Este artículo puede leerse traducido al español en:

http://www.elprofesionaldelainformacion.com/contenidos/2015/jul/02_esp.pdf

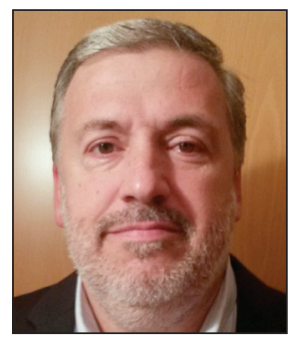

Pere Masip is a professor of journalism at the University of Ramon Llull, where he also gained his $\mathrm{PhD}$ in journalism. He is the main researcher of the research group Digilab: media, strategy and regulation. His main research interests are media convergence, digital journalism, and the impact of technology on journalistic and communication practices. He has participated in several national and international projects. He is currently coordinating a research, development, and innovation project funded by the Spanish Ministry of Economy and Competitiveness entitled Active audiences and journalism: engaged citizens or motivated consumers? He is the author of numerous articles and books. https://orcid.org/0000-0002-8231-0824

peremm@blanquerna.url.edu

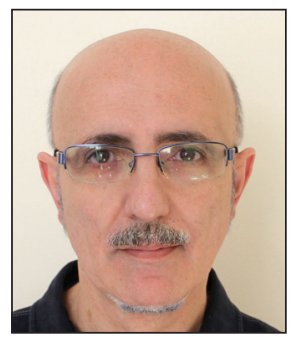

Javier Guallar holds a PhD in Information and Documentation, and is a professor with the Faculty of Library and Information Science at the University of Barcelona, Blanquerna School of Communication and International Relations at the University of Ramon Llull, Information and Communication Studies at the Open University of Catalonia, and Communication at the International University of Catalonia; he also lectures at other universities. His main research interests are documentation in the media, digital journalism, sources of information, scientific publishing, and content curation. He has authored numerous articles and several books, such as Prensa digital y bibliotecas (Trea, 2009) and El content curator (UOC publishing house, 2013).

https://orcid.org/0000-0002-8601-3990

jguallar@gmail.com

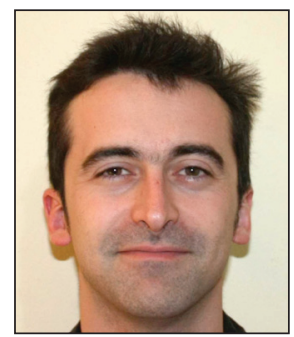

Jaume Suau holds a PhD in communication, and is a researcher at the Blanquerna School of Communication and International Relations at the University of Ramon Llull. He is a member of the research group Digilab: media, strategy and regulation. His main research interests are the effects of new digital technologies on society and journalistic practice. He is also project manager of the European-funded project Med media, aimed at improving journalism in North African and Middle Eastern countries.

http://orcid.org/0000-0003-4480-4441

jaumesm@blanquerna.url.edu

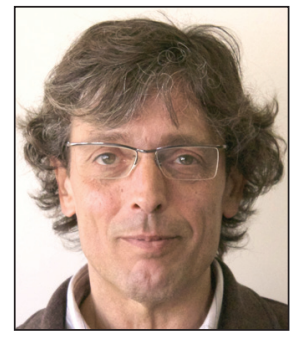

Carlos Ruiz-Caballero holds a PhD in journalism and is a professor at the Blanquerna School of Communication and International Relations at the University of Ramon Llull. His main research interests are media convergence, digital journalism, and active audiences from the perspective of ethics of communication. He was awarded the Josep Vallverdú 2014 essay award for the play The digitization of the other. He is the author of La agonía del cuarto poder, Prensa contra democracia (Trípodos, 2008) and Ética de la audiencia (Grafite, 2003). He has participated in several national research projects and has published in journals such as International journal of press and politics and Communication and society. He is a member of the Council of Information of Catalonia. https://orcid.org/0000-0002-1395-2145 


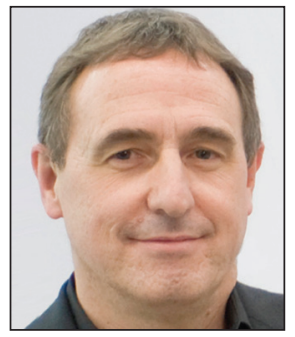

Miquel Peralta holds a PhD in journalism and is a professor at the Blanquerna School of Communication and International Relations at the University of Ramon Llull, where he teaches television journalism language and lectures at various postgraduate courses. He is also part of the research group Digilab: media, strategy and regulation. He combines his university teaching with television journalism on Radio Televisión Española. He currently directs the television programme on entrepreneurs I've an idea (shown on channel La2). He has participated at various national and international conferences on journalism and television audiences. He is the author, among others, of the book Teleinformativos: La noticia digital en televisión (UOC publishing house). His main research interests are digital news on television, the production processes of television news, and audiences in television.

http://orcid.org/0000-0001-9842-4538

miquelperaltam@blanquerna.url.edu

Universitat Ramon Llull, Facultat de Comunicació i Relacions Internacionals Blanquerna Plaça Joan Coromines, 08001 Barcelona, España

\begin{abstract}
Based on a quantitative approach, this paper presents some of the preliminary results of a research project focused on the analysis of the motivations that encourage citizens to actively participate in online news media, using the mechanisms provided by their websites, and through open social network platforms. The findings show that, although there is a widespread discourse of distrust in connection to journalists and the traditional media institutions, as well as general criticism of the actual practices of journalists, the common understanding of the participatory dimension of the media does not entail discourses of change or modification of the existing hegemony. Instead of turning to alternative sources, such as citizen journalism or non-traditional media, or taking the lead by creating their own content, citizens prefer to continue to respect journalism as a profession and the traditional media institutions as the main producers of news as well as the most trusted sources of information. Furthermore, although in previous studies audience participation "in" the media has been highlighted, the findings of this research show that the practice of user recommendation or dissemination of media content through social networks has been adopted by a large number of citizens.
\end{abstract}

\title{
Keywords
}

Participatory journalism; Active audiences; UGC; Online journalism; Social networks; Surveys.

\section{Resumen}

Este artículo presenta los primeros resultados de un proyecto de investigación centrado en el análisis de las motivaciones que impulsan a los ciudadanos a participar activamente a través de los mecanismos que con ese fin ofrecen los medios digitales y a través de las redes sociales. Los resultados muestran que a pesar de los discursos generalizados de desconfianza en torno a los periodistas y los medios de comunicación tradicionales, así como las quejas generales sobre la práctica de la profesión periodística, la dimensión participativa de los medios de comunicación no conlleva un discurso o modificación de las hegemonías existentes. En lugar de recurrir a fuentes alternativas (como el periodismo ciudadano o medios no tradicionales), o generar contenidos informativos propios, los ciudadanos siguen confiando en los periodistas y los medios tradicionales como los principales productores de noticias, así como las fuentes de información de mayor confianza. Por otra parte, aunque tradicionalmente se ha destacado la participación de las audiencias "en" los medios, los resultados muestran que las prácticas de recomendación o diseminación en redes sociales de contenidos previamente elaborados por los medios son asumidas por un número importante de ciudadanos.

\section{Palabras clave}

Periodismo participativo; Audiencias activas; Contenidos generados por los usuarios; Periodismo digital; Redes sociales; Encuestas.

Masip, Pere; Guallar, Javier; Suau, Jaume; Ruiz-Caballero, Carlos; Peralta, Miquel (2015). “News and social networks: audience behavior". El profesional de la información, v. 24, n. 4, pp. 363-370.

http://dx.doi.org/10.3145/epi.2015.jul.02

\section{Introduction}

Symbolic power, as Thompson defined it (1985), is no longer exclusively a media monopoly thanks to the advent of web 2.0 , social networks, and active audiences. The participatory potential of new media enables citizen generated content to be produced and disseminated. This development has led to the frequent prediction of the demise of traditional media (Negroponte, 1995; Sabadín, 2007; Nerone, 2009) and a deluge of what is referred to as citizen journalism (Gilmor, 2007; Rosen, 2006). Other authors envisage hybrid scenarios, based on co-operation between professional and citizen journalists (Bruns, 2005). 
Over and above the discussion about a future without professional journalists or the media, the fact is that in a little less than a decade journalists have sought to turn the audience into more than just readers. The public are invited to share their views -even though they are not always listened to (Masip; Micó, 2010)- and encouraged to develop and contribute their own content (Guallar, 2007). The new relationship between media and audiences, despite having been driven by the newspaper companies, was received with an ambivalent attitude by journalists (Chung, 2007; Domingo et al., 2008; Singer, 2010; Harrison, 2010; Wardle; Williams, 2010). Aware of the enormous potential of audience participation, particularly as a source, journalists gladly welcomed comments, although sometimes bemoaned the tone used, and opened the doors to citizens to send in their material. Journalists were aware that, with unplanned news, journalists would always be the last ones on the spot and that the images captured by witnesses added immediacy, spontaneity, authenticity, and proximity. On the other hand, journalists have been critical of any initiative that could compromise their gatekeeper role or bring changes to their routines and pre-existing values (Harrison, 2010; O'Sullivan; Heinonen, 2008; Quandt, 2008; Wardle; Williams, 2010; Williams et al., 2010).

Despite the potential professionals offer for journalism, the prevalence of participatory mechanisms is mainly due to economic motivations (Singer et al., 2011; Vujnovic et al., 2010, Rosenstiel; Michell, 2011; Becker; Clement; Schaedel, 2010). The participation of citizens "in" and "through" the media (Carpentier, 2011) is conceived as a strategy to generate traffic, attract visitors and, as far as possible, build their loyalty. In contrast, academic discourse tends to study the phenomenon of participation from a regulatory perspective, linked to the democratic role of the media, taking for granted the audience's desire to participate and criticizing the lack of enthusiasm of most media and journalists in implementing formats that enable the public to participate more directly in news content (Borger et al., 2013).

As noted above, social networks have often been perceived as a way to challenge the hegemony of the media because they channel participation from media-controlled platforms to open ones. However, at the same time social networks have also materialized as an interesting tool for the media, given that they enable dissemination of content, encourage interaction, and are cheap

Certainly, social media, together with blogs, facilitate the proliferation of voices, which are often ignored by the media (Lowrey, 2006; Domingo; Heinonen, 2008). However, research shows that social media have not altered the essence of professional practice. Bloggers who are not journalists are reluctant to define themselves as agents of change in journalism or in competition with journalists (Matheson, 2004). And when they seek to become established as authors online, they replicate the routines of the profession, rather than creating new ones (Lowrey; Latta, 2008).

Researchers have given great attention to exploring the use of social networks in journalistic practice (Hermida; Thurman, 2008; García-Torres et al., 2011; Herrera-Damas,
2013; Palomo, 2014; Palomo; Meso, 2014). However, there is little information regarding the public's attitude towards the participatory options and the use of social networks as a source of news. Many of the studies that have focused on the audience were limited to describing their usage preferences (Boczkowski; Mitchelstein, 2013. Haise et al. (2013) took a more comprehensive approach, comparing the attitude of journalists and audiences in relation to participation and motivation to participate. While there is consensus between the two groups on the role of journalists and participation, the differences are more significant with reference to motivation. Journalists attribute audience participation to emotional motivations and self-interest, whereas users stress that they take part to develop their knowledge and to contribute topics of interest to them.

The use of social networks is associated with friends and relationships, however, the second most popular activity in social networks is accessing news

\section{Objectives and methodology}

This article is part of a broader research project ${ }^{1}$ with the general objective to study active audiences -i.e. users of digital media who interact through the participatory mechanisms made available to them by news companies- their profiles, their motivations, their habits, and the content they produce. In this context, it also aims to determine which media, in the public's opinion, best achieve the democratic function assigned to the media, and the media role in a networked society in which any member of the public is a potential broadcaster of news.

This general objective has been subdivided into five specific objectives, which relate to the study of: a) access to news through social networks; b) digital media as a source of news; c) audience participation as a counterweight to the media; d) the relationship between participation and credibility; and e) the relationship between the media, pluralism, and democracy. This article sets out the findings that relate to the first of these specific objectives - that of access to news through social networks-.

To meet the objectives described, in this research a dual approach to the subject matter was selected, both quantitative and qualitative. This article only presents the findings of the quantitative approach based on a panel conducted in cooperation with the Associación para la Investigación de los Medios de Comunicación (Association for Media Research) (AIMC). The qualitative approach was subsequently implemented by bringing together twelve focus groups, which are currently being analysed.

Therefore, the quantitative study was developed through an agreement with AIMC, a consortium created in 1988 by media companies and advertisers to measure and monitor audience ratings. This cooperation allowed, firstly, questions related to this research project to be included on the 
questionnaire used by the $A I M C$ in its 2013 study on internet users, Navegantes en la Red, and secondly, the creation of the panel which is the subject of this article.

The panel consisted of 591 individuals who were interviewed by the AIMC team between December 2013 and February 2014. Participants answered a questionnaire including 67 questions, which had previously been discussed with the AIMC technical committee to ensure that it met the pre-requisites for the methodological tools used. To select the sample, a multi-stage, stratified random sample procedure was employed, guaranteeing the representativeness of the sample for the internet user population (all over 14 years old).

The questions used pursued a general aim of obtaining detailed information on online news consumption habits, understanding the motivations leading citizens to participate in social networks and through participatory mechanisms in digital media, and learning about the role they ascribe to their involvement in the operation of the media. The 67 questions were grouped into the five major areas described above and this article is based on data from the first major area.

\section{More than half of users follow at least} one news medium through social networks and almost a third follow at least one journalist

\section{Findings}

In the Internet era, television is still the most popular news medium for Spaniards, cited by $56.8 \%$ of the population (CIS, 2013). However, the Internet plays an increasingly large part in Spaniards' news consumption. According to the Navegantes en la Red study (AIMC, 2014), more than half of Internet users, $66.4 \%$, consider the Internet to be a key source of information, and $29.1 \%$ consider it a secondary but important source. The percentages of individuals for whom the Internet is not an important source of information or who simply never use it are extremely low, 3.0 and $1.2 \%$, respectively.

The data from Navegantes en la Red, supported by our panel, confirm that social networks have penetrated very significantly in Spaniards' use of the Internet. $74.2 \%$ of Internet

Table 1. What do you use social networks for?

\begin{tabular}{|l|r|r|}
\hline & \multicolumn{1}{|c|}{ Total $^{\mathbf{2}}$} & \multicolumn{1}{c|}{$\%$} \\
\hline Relationships with friends / acquaintances & 19,645 & 88.1 \\
\hline Family relationships & 9,765 & 43.8 \\
\hline Professional relationships & 7,203 & 32.3 \\
\hline Search for a partner & 444 & 2.0 \\
\hline Hobbies & 8,381 & 37.6 \\
\hline Access to news & 10,725 & 48.1 \\
\hline Others & 1,291 & 5.8 \\
\hline
\end{tabular}

Data weighted by the AIMC, in thousands.

Percentages do not add up to 100 because more than one answer could be given. users use social networks daily and $11.6 \%$ at least once a week, which is a higher percentage than those who have never used them. We set out below the results of the panel carried out in our study.

\section{Use of social networks}

In line with the trend observed in other countries (Newman; Levy, 2014), the most popular social networks are Facebook, used by $91 \%$ of Internet users, and secondly, although quite a long way behind, Twitter, used by $39.8 \%$. The next most popular are LinkedIn (19.4\%), Google+ (17.3\%) and Instagram (13.6\%).

Having confirmed the widespread use of social networks by the Spanish population, it is of interest to learn, from the point of view of the objectives of this study, how big a role they have in accessing news. To do so, several questions were posed to the individuals who reported being users of either of the two biggest social networks, Facebook or Twitter.

First, respondents were asked what they used social networks for (table 1). It was found that the leading use is relationships with friends and acquaintances (88.1\%), but after this, it is striking that the second principal use is to access news (48.1\%). This confirms that in the new social media world, citizens still have the same need to access news content, or at least half of users state that they use social networks for this purpose.

The data from the survey highlight the dual role of social media users with regard to news: as consumers and as recommenders

\section{Social networks and news}

In terms of how users access news on social networks, friends are the principal channel, $81.2 \%$ of users receiving news recommendations from friends. In second place is the media, almost half of users (47.5\%) stating that the media recommended the news items (table 2).

The findings are consistent with the fact that more than half of social network users state that they "follow" at least one news medium, and, in addition, $30.2 \%$ follow at least one individual journalist (table 3 ). The first figure highlights the

Table 2. Source of the news received through social networks

\begin{tabular}{|l|r|c|}
\hline & Total & $\%$ \\
\hline Media & 11,416 & 47.4 \\
\hline Associations, NGOs... & 7,232 & 30.0 \\
\hline Companies & 3,849 & 16.0 \\
\hline Friends & 19,555 & 81.2 \\
\hline Journalists & 5,010 & 20.8 \\
\hline Celebrities & 3,525 & 14.6 \\
\hline
\end{tabular}

Data weighted by the $A I M C$, in thousands.

Percentages do not add up to 100 because more than one answer could be given. 
Table 3. Following of media and journalists in social networks

\begin{tabular}{|l|c|c|}
\hline & Total & $\%$ \\
\hline Media & 11,196 & 52.8 \\
\hline Journalists & 6,401 & 30.2 \\
\hline Others & 9,065 & 42.8 \\
\hline
\end{tabular}

Data weighted by the $A I M C$, in thousands.

Percentages do not add up to 100 because more than one answer could be given.

importance of traditional media in the new social media environment, and the second points to the increasing role online of the journalist as a brand, given that almost a third of social network users follow journalists.

In addition, the data in the two tables show the important role of the media (and journalists) in accessing news through social networks. In fact, we should not lose sight of the fact the news recommended by friends was produced by professional journalists. Friends are the new news gatekeepers. However, bearing in mind the way of accessing news online described above, Internet users make their selection from the news previously selected by the media and journalists. What may be different is the hierarchization of news and the agreement or disagreement expressed by the active audience regarding the viewpoint from which a story is approached.

Despite the credibility problem facing journalists (FariasBatlle, 2011; Casero-Ripollés, 2014), citizens consider the information produced by professional journalists to be more reliable than that produced by non-professionals (table 4).

Table 5 shows the responses to the question about the frequency with which news is received on Facebook and Twitter, and table 6 shows the frequency with which news is shared in them (social recommendation of news). It is useful to compare the findings.

Firstly (table 5), we find that 55\% of Facebook and Twitter users receive news from the media very frequently (daily) and $25 \%$ fairly frequently (last 7 days). Therefore, combining these two figures, there is clearly a significant number of users consuming news through social networks, a total of $80 \%$ of users.

Secondly (table 6), the action of sharing or recommending news through social networks, although not reaching such high percentages, is very substantial, half of users recommending news items very frequently (daily) or fairly frequently (last 7 days).

Table 5. Frequency with which news is received through social networks

\begin{tabular}{|l|c|c|}
\hline & Total & $\%$ \\
\hline Yesterday & 11,686 & 55.1 \\
\hline Last 7 days & 5,423 & 25.6 \\
\hline Last 30 days & 1,574 & 7.4 \\
\hline Last year & 750 & 3.5 \\
\hline Longer ago / Never & 1,757 & 8.3 \\
\hline & & 100 \\
\hline
\end{tabular}

Table 4. To what extent do you consider the news produced by ... to be reliable, error-free and unbiased?

\begin{tabular}{|l|c|c|c|c|}
\hline & \multicolumn{2}{|c|}{ Professional journalists } & \multicolumn{2}{c|}{ Non-professional journalists } \\
\hline & Total & $\%$ & Total & $\%$ \\
\hline Very & 2,599 & 9.9 & 871 & 3.3 \\
\hline Quite & 14,085 & 53.9 & 9,546 & 36.5 \\
\hline Not very & 8,591 & 32.9 & 13,700 & 52.4 \\
\hline Not at all & 876 & 3.3 & 2,034 & 7.8 \\
\hline
\end{tabular}

Data weighted by the $A I M C$, in thousands.

The findings confirm the importance of news on social networks. However, different patterns of behavior are observed, depending on whether news is received or shared. For the sharing of news, significant differences were detected, confirming that users are not as active as certain authors have maintained (Bruns, 2005), but are still a significant minority.

Various studies confirm there is a significant minority of users who actively participate in the news reporting process, providing information to journalists, commenting on news and redistributing it on social networks, for example, $37 \%$ of internet users in the US (Purcell et al., 2010). In fact, users are more likely to respond to another's contribution than contribute original ideas.

The recommendation and receipt of news is complemented by another illustrative indicator, the percentage of users who read the news they receive. In this case, it is noteworthy that $59 \%$ of users state they usually read it and $22.7 \%$ occasionally (table 7). These figures contradict the supposition that audiences read little of the content shared or received from other Internet users.

The responses to the question on the news topics accessed through Facebook and Twitter (table 8) show a preference for local news (62.5\%), followed by national politics (50\%)

Table 6. Frequency with which news is shared through social networks

\begin{tabular}{|l|c|c|}
\hline & Total & $\%$ \\
\hline Yesterday & 5,540 & 26.1 \\
\hline Last 7 days & 5,247 & 24.8 \\
\hline Last 30 days & 3,463 & 16.3 \\
\hline Last year & 2,374 & 11.2 \\
\hline Longer ago / Never & 4,564 & 21.5 \\
\hline & & 100 \\
\hline
\end{tabular}

Data weighted by the $A I M C$, in thousands.

Table 7. Frequency with which news received through social networks is read

\begin{tabular}{|l|c|c|}
\hline & Total & $\%$ \\
\hline Usually & 15,402 & 58.9 \\
\hline Occasionally & 5,949 & 22.7 \\
\hline Rarely & 2,731 & 10.4 \\
\hline Never & 2,069 & 7.9 \\
\hline & & 100 \\
\hline
\end{tabular}

Data weighted by the $A I M C$, in thousands. 
Table 8. News topics shared through social networks

\begin{tabular}{|l|r|r|}
\hline & Total & $\%$ \\
\hline Local news & 15,048 & 62.5 \\
\hline Local political news & 8,517 & 35.4 \\
\hline National political news & 12,172 & 50.5 \\
\hline International news & 8,185 & 34.0 \\
\hline Economy & 7,592 & 31.5 \\
\hline Society & 8,133 & 33.8 \\
\hline Health and medicine & 7,323 & 30.4 \\
\hline Weather & 5,439 & 22.6 \\
\hline Science and technology & 6,317 & 26.2 \\
\hline Traffic & 1,009 & 4.2 \\
\hline Culture & 10,203 & 42.4 \\
\hline Sports & 8,976 & 37.3 \\
\hline Celebrity news & 2,880 & 12.0 \\
\hline Others & 2,383 & 9.9 \\
\hline
\end{tabular}

Data weighted by the $A I M C$, in thousands.

Percentages do not add up to 100 because more than one answer could be given.

and then, with similar percentages of between 42.4 and $33.8 \%$, culture, sports, community politics, international, and society news.

The answers are not particularly relevant as they do not define significant differences between some of the main news sections in the media. The sole exception is the confirmation of Internet audiences' interest in local news.

Subjects were also asked about their affinity with the media publishing the news they access through social networks and email (table 9). A high percentage, as expected, come from the media they usually consult, but it is remarkable that more than a quarter of the news $(26.1 \%)$ is published by media the users do not usually read and $7.2 \%$ are from media that have a different ideological stance from their own.

This data can be interpreted in a moderately positive way, in that the internet and social networks are allowing some access to the content of media users do not usually consult, and are even ideologically opposed, which in other news consumption contexts would be more difficult. This issue must be given careful consideration in future studies, since a consolidated trend of this kind would help to increase pluralism, essential for enhancing the democratic culture of society.

\section{Conclusions and discussion}

Social networks are part of the digital menu of Spanish Internet users. Over $74 \%$ of regular Internet users had accessed social networks the previous day (AIMC, 2014). Following the trend in other countries, Facebook has become the dominant social network, followed a long way behind by Twitter.

As expected, the use of social networks is associated with friends and relationships, however, significantly, the second most popular activity in social networks is accessing news. The media, although often criticised, still play an important
Table 9. Source of the news received through social networks

\begin{tabular}{|l|c|c|}
\hline & Total & $\%$ \\
\hline Media usually consulted & 18,637 & 77.4 \\
\hline Media not usually consulted & 6,281 & 26.1 \\
\hline $\begin{array}{l}\text { Media with different ideological posi- } \\
\text { tions to the user's own }\end{array}$ & 1,741 & 7.2 \\
\hline
\end{tabular}

Data weighted by the AIMC, in thousands.

Percentages do not add up to 100 because more than one answer could be given.

role, since more than half of users follow at least one news medium through social networks and almost a third follow a journalist.

As a result of the homogenisation of content (Boczkowski, 2010) the media brand loses importance. Readers obtain news through search engines and now also through social networks. The important thing is what is said, not who says it or how they say it, therefore the brand ceases to be crucial. This, along with the credibility problems suffered by the media, might lead one to think that the media and journalists would lose importance online. However, in fact that is not the direction things are developing in. Citizens rely more on professional journalists than on what non-professional citizen journalists can produce. Professional journalists, whilst criticised, are recognised as a fundamental institution of democratic systems and have a known affiliation, which is not the case of citizen journalists. As a result, a significant proportion of the public follow individual journalists, who build a personal brand necessarily based on their professionalism and credibility.

\section{Even though initially it is the media who determine the news content, in practice it is the public who with a 'like' or tweet define the interest of a piece of news}

The data from the survey highlight the dual role of social network users with regard to news: as consumers and as recommenders. $81 \%$ of the news items received through social networks come from "friends". Here we have a paradox, as the journalist is no longer the sole gatekeeper. Although journalists cling to this function, it is apparent they are progressively giving way to new players. The public become what Singer (2013) calls secondary gatekeepers. Even though initially it is the media who determine the news content, in practice it is the public who with a "like" or tweet define the interest of a piece of news and whether it is worth giving it visibility. In this way, they create a new hierarchization of the news selected by the media and journalists.

In fact, although most Internet users receive news from the media they usually follow, it is significant that the social networks prompt access to news media that are not part of their regular news diet and even from ideologically opposed media. This points to an increase in the pluralism of news consumed. 
Despite the pessimism that sometimes pervades discussions on the future of journalism, encouraging trends can be drawn from our findings. In the era of web 2.0, participation and social networks, citizens continue to demand news. People want information, they want to be informed, especially in matters of public interest, and they share the information they consider to be relevant or interesting.

What has changed is the means of accessing the news and the way of relating to it, which is no longer a unidirectional flow. Although the media still retain a central role, other players such as search engines and social networks are becoming increasingly important. The information reaches us, therefore, through multiple channels and the public are empowered by determining what will be treated as news and what will not. In addition, the data from this study draw attention to audiences' limited desire to participate. While traditionally a greater value has been given to the participation of citizens "in" the media (Carpentier, 2011) through forms which have a limited take-up by the audience such as the creation of news content, the practices of recommendation or dissemination of content previously produced by the media are being adopted by a greater number of citizens. They involve a lower participatory intensity, but have the potential to impact more heavily on the political and media agenda. The citizen is no longer subject to the passive consumer-active producer dichotomy, and in the new media environment intermediary roles and low-intensity participatory practices assume greater importance.

Social networks instigate access to news media that are not part of their regular news diet and even from ideologically opposed media

\section{Notes}

1. This work is part of a project funded by the Spanish Ministry of Economy and Competitiveness, Ref.: CSO201239518-C04-01

2. The findings set out in this article are original and have never been published. The tables show data from surveys conducted for this research according to the AIMC Q Panel methodology. The data have been weighted by the AIMC in thousands; for example, in the first question in table 1 , the estimation of users who use the internet to interact with their friends and acquaintances is $19,645,000$ people, representing $88.1 \%$ of the Spanish population of internet users over 14 .

\section{Bibliography}

AIMC (2014). Navegantes en la Red.

http://download.aimc.es/aimc/974_ryRa6/macro2014.pdf

Bergström, Annika (2008). "The reluctant audience: online participation in the Swedish journalistic context". Westminster papers in communication and culture, v. 5, n. 2, pp. 60-80. https://www.westminster.ac.uk/_data/assets/pdf file/0012/20019/005WPCC-Vol5-No2-Annika_Bergstrom.pdf
Boczkowski, Pablo J. (2010). News at work: imitation in an age of information abundance. Chicago: University of Chicago Press. ISBN: 9780226062785

Boczkowski, Pablo J.; Mitchelstein, Eugenia (2013). The news gap: when the information preferences of the media and the public diverge. Cambridge: The MIT Press. ISBN: 9780262019835

Borger, Merel; Van-Hoof, Anita; Costera-Meijer, Irene; Sanders, José (2013). "Constructing participatory journalism as a scholarly object". Digital journalism, v. 1, n. 1, pp. 117-134. http://dx.doi.org/10.1080/21670811.2012.740267

Bruns, Axel (2005). Gatewatching: collaborative online news production. New York: Peter Lang. ISBN: 0820474320

Carpentier, Nico (2011). Media and participation. Chicago: The University of Chicago Press. ISBN: 9781841504070

Casero-Ripollés, Andreu (2014). "La pérdida de valor de la información periodística: causas y consecuencias". Anuario ThinkEPI, v. 8, pp. 256-259.

http://recyt.fecyt.es/index.php/ThinkEPI/article/view/29589

CIS (2013) Barómetro de marzo.

http://www.cis.es/cis/export/sites/default/-Archivos/ Marginales/2980_2999/2981/Es2981.pdf

Domingo, David; Heinonen, Ari (2008). "Weblogs and journalism: a typology to explore the blurring boundaries". Nordicom review, v. 29, n. 1, pp. 3-15.

http://jclass.umd.edu/classes/jour698m/domingoblogs.pdf

Domingo, David; Quandt, Thorsten; Heinonen, Ari; Paulussen, Steve; Singer, Jane B.; Vujnovic, Marina (2008). "Participatory journalism practices in the media and beyond. An international comparative study of initiatives in online newspapers". Journalism practice, v. 2, n. 3, pp. 326-342. http://dx.doi.org/10.1080/17512780802281065

Farias-Batlle, Pedro (2011). Informe anual de la profesión periodística 2011. Madrid: Asociación de la Prensa de Madrid. http://www.apmadrid.es/images/stories/Informe\%20 APM\%202011.pdf

García-de-Torres, Elvira; Yezers'Ka, Lyudmyla; Rost, Alejandro; Calderín, Mabel; Edo, Concha; Rojano, Miladys; Said, Elías; Jerónimo, Pedro; Arcila, Carlos; Serrano, Ana; BadiIlo, Jorge; Corredoira, Loreto (2011). "Uso de Twitter y Facebook por los medios iberoamericanos". El profesional de la información, v. 20, n. 6, pp. 611-620.

http://dx.doi.org/10.3145/epi.2011.nov.02

Gillmor, Dan (2004). We the media. Grassroots journalism by the people, for the people. Sebastopol, USA: O'Reilly. ISBN: 9780596102272

Guallar, Javier (2007). "La renovación de los diarios digitales: rediseños y web 2.0". El profesional de la información, v. 16, n. 3, pp. 235-242.

http://www.elprofesionaldelainformacion.com/contenidos/2007/ mayo/08.pdf

http://dx.doi.org/10.3145/epi.2007.may.08

Heise, Nele; Loosen, Wiebke; Reimer, Julius; Schmidt, JanHinrik (2013). "Including the audience: Comparing the at- 
titudes and expectations of journalists and users towards participation in German TV news journalism". Journalism studies, v. 15, n. 4, pp. 411-430.

http://dx.doi.org/10.1080/1461670X.2013.831232

Hermida, Alfred; Thurman, Neil (2008). "A clash of cultures: The integration of user-generated content within professional journalistic frameworks at British newspaper websites". Journalism practice, v. 2, n. 3, pp. 343-356. http://dx.doi.org/10.1080/17512780802054538

Herrera-Damas, Susana (2013). “Indicaciones recurrentes en las normativas para el uso periodístico de las redes sociales". El profesional de la información, v. 22, n. 1, pp. 46-53. http://dx.doi.org/10.3145/epi.2013.ene.06

Lowrey, Wilson (2006). "Mapping the journalism-blogging relationship". Journalism, v. 7, n. 4, pp. 477-500.

http://citeseerx.ist.psu.edu/viewdoc/download?doi=10.1.1. 91.4357\& $r e p=$ rep1\&type $=p d f$

http://dx.doi.org/10.1177/1464884906068363

Lowrey, Wilson; Latta, John (2008). "The routines of blogging". En: Paterson, C. y Domingo, D. (eds.) Making online news: the ethnography of online news. New York: Peter Lang. ISBN: 9781433102141

Masip, Pere; Micó, Josep-Lluís (2010). La convergència comunicativa a la premsa local i comarcal: noves perspectives per a la informació. Barcelona: Generalitat de Catalunya: Premsa Comarcal. ISBN: 9788439386568

http://catalogo.rebiun.org/rebiun/record/Rebiun09714874

Matheson, Donald (2004). "Negotiating claims to journalism: webloggers' orientation to news genres". Convergence, v. 10 , n. 4 , pp. 33-54

http://dx.doi.org/10.1177/135485650401000405

Negroponte, Nicholas (1995). Being digital. London: Hodder and Stoughton. ISBN: 0340649305

Nerone, John (2009). "The death (and rebirth?) of working class journalism". Journalism, v. 10, n. 3, pp. 353-355. http://dx.doi.org/10.1177/1464884909102596

Newman, Nic; Levy, David A. (eds.) (2014). Reuters Institute digital news report 2014. Oxford: Reuters Institute for the Study of Journalism.

http://bit.ly/digitalnews2014

Palomo-Torres, Bella (2014). “La (r)evolución social del pe- riodista". Telos, n. 98.

http://goo.gl/KzHfz5

Palomo-Torres, Bella; Meso, Koldo (2014). "El mito de la conversación con el medio: el caso de Facebook". En: González, J. E. y Valderrama, M. (coords.). Comunicación actual: redes sociales y lo 2.0 y 3.0. Madrid: McGraw Hill, pp. 453470. ISBN: 9788448197469

Sabadin, Vittorio (2007). The last issue of The New York times: the future of newspapers. Barcelona: Sol90. ISBN: 978 8498207736

Singer, Jane B. (2010). "Quality control". Journalism practice, v. 4, n. 2, pp. 127-142.

http://dx.doi.org/10.1080/17512780903391979

Singer, Jane B. (2013). “User-generated visibility: Secondary gatekeeping in a shared media space". New media \& society, v. 16, n. 1 , pp. 55-73.

http://dx.doi.org/10.1177/1461444813477833

Singer, Jane B.; Domingo, David; Heinonen, Ari; Hermida, Alfred; Paulussen, Steve; Quandt, Thorsten; Reich, Zvi; Vujnovic, Marina (2011). Participatory journalism: guarding open gates at online newspapers. Oxford: Wiley-Blackwell. ISBN: 9781444332261

Thompson, John B. (1985). The media and modernity: a social theory of the media. Cambridge: Polity, 322 pp. ISBN: 9780745656748

Vujnovic, Marina; Singer, Jane B.; Paulussen, Steve; Heinonen, Ari; Reich, Zvi; Quandt, Thorsten; Hermida, Alfred; Domingo, David (2010). "Exploring the political-economic factors of participatory journalism". Journalism practice, $v$. 4, n. 3, pp. 285-296. http://dx.doi.org/10.1080/17512781003640588

Wardle, Claire; Williams, Andrew (2010). "Beyond usergenerated content: a production study examining the ways in which UGC is used at the BBC". Media, culture \& society, v. 32, n. 1, pp. 781-799.

http://dx.doi.org/10.1177/0163443710373953

Williams, Andrew; Wardle, Claire; Wahl-Jorgensen, Karin (2010). "Have they got news for us? Audience revolution or business as usual at the BBC?". Journalism practice, v. 5, n. 1, pp. 85-99.

http://dx.doi.org/10.1080/17512781003670031 